\title{
The Need For Achievement, Risk-Taking Propensity, And Entrepreneurial Intention Of The Generation Z
}

\author{
Dea Sawitri Fauzia, Tri Siwi Agustina* \\ Airlangga University, Indonesia
}

\begin{abstract}
Entrepreneurial intention is affected by various factors, namely the need for achievement and risk-taking propensity. This study aims to fill a research gap regarding numerous previous studies about Student Entrepreneurship Program (PMW). However, there has not been a study that involved the need for achievement and risk-taking propensity by mediating entrepreneurial attitudes as a form entrepreneurial intention among the Generation Z of PMW participants. The research approach is quantitative by distributing questionnaires to 61 Generation Z who were the participants of PMW 2020. Hypothesis tests were carried out by the Path Analysis. The results of this study indicated that: the need for achievement and the risk-taking propensity was proven to positively influence entrepreneurial intentions; however, the entrepreneurial attitude was not proven to mediate the influence of the need for achievement on entrepreneurial intentions; as well as the entrepreneurial attitude was not proven to mediate the influence of the need for achievement on entrepreneurial intentions.
\end{abstract}

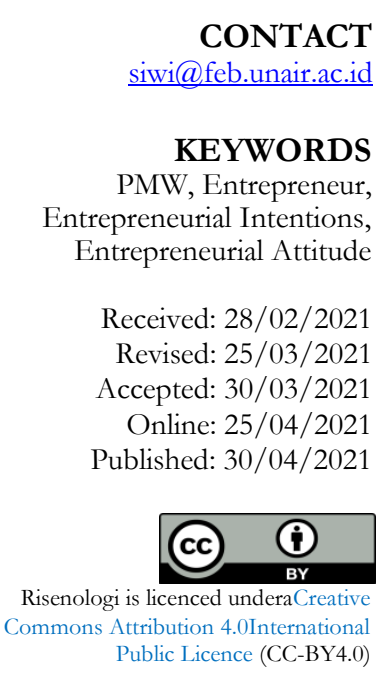

\section{INTRODUCTION}

The Student Entrepreneur Program, as commonly known as Program MahasiswaWirausaha (PMW), is one of the DIKTI priority programs which aims to instill an entrepreneurial mindset in students, forms a strong entrepreneurial character to students, provides entrepreneurial soft skills to students, and provides entrepreneurial learning facilities and infrastructure for students. The implementation of PMW is delegated to universities. The implementation of this program is expected to create new entrepreneurs among students. If more and more undergraduate graduates become entrepreneurs, the more job vacancies will take more labors.

This research was conducted at Airlangga University, in consideration that Airlangga University is committed to not only preparing students to become graduates, but also ready to become entrepreneurs. Therefore, Airlangga University provides facilities for students who want to learn to start a business in a structured manner under the guidance of Pusat PembinaanKarir dan Kewirausahaan (Career and Entrepreneurship Development Center of Airlangga University) and Business Incubator of Airlangga University(Unair News, 2018).

Based on an interview in mid of April 2020, with the Chairperson of the Career and Entrepreneurship Development Center at PPKK as the executor of PMW at Airlangga University, PMW has been held 13 times. In addition, until 2020, it has been recorded that the PMW has been held for 13 years in Airlangga University. During that time, many new entrepreneurs were produced (Unair News, 2018)

As an illustration, PMW is implemented in a period of 8 months. Requirements for students to participate in PMW are active students of Airlangga University, at maximum in semester 6, have a business for at least 6 months, and must submit a business profile along with a business development plan that will be carried out. Submission of proposals can be done individually or in groups (1 group consists of a maximum of 4 people). The implementation of the program begins with the initial stage of selection, interviews, assignments to implement business projects 1, 2 and 3, selection to pass funding and receiving revolving funds for business capital assistance. To be able to run business projects, both individuals and in groups participants received assistance from successful entrepreneurs during the program. Not only mentoring, there are various forms of hard skill and soft skill training aimed at equipping participants to be ready to enter the business world.

Related to the requirements for participation in PMW, which is for students in a maximum of $6^{\text {th }}$ semester, PMW participants in 2020 are classified as generation $Z$ or the centennial generation, namely the generation born between 1996 and 2010 or after the millennial generation (generation Y). Generation Y was raised by the internet and social media. Millennial generation is considered to have entrepreneurial potential and enormous market potential, because of their ability to obtain public information and open jobs in accordance with market 
needs(Henley, 2017) and Gonzales (2011). However, they do not yet have entrepreneurial readiness thus it must be followed by the ability to carry out entrepreneurial analysis (Arrighetti et al., 2014). According to Purnomo et al.,(2019), Generation Z continues the spirit of the previous generation to choose entrepreneurship for various reasons, namely not wanting to be restricted, college is not a guarantee of success, freelance and peer to peer service sites, social media can be found and used easily, access to self-development is easy, including getting mentors.

This study is important for the following reasons: first, research on PMW have been carried out a lot, where the majority of studies discovered contextual factors that influence entrepreneurial intentions such as entrepreneurial attitudes Zamzami(2016) andSumadi\&Sulistyawati, (2017), motivasi and environment (Sumadi \& Sulistyawati, 2017), subjective norms and perceived behavioral control(Zamzami, 2016). From this series of studies, there have been no studies that examine other personality factors: such as need for achievement and other contextual factors such as risk-taking propensity from PMW participants. Even though the need for achievement is important to form the intention to become an entrepreneur (Akhtar et al., 2020). Furthermore, risk-taking propensity is also important in shaping entrepreneurial intentions because individuals who dare to take risks will appear confident in facing various obstacles that hinder their intention to become an entrepreneur(Gu et al,2018)

Secondly, a previous research was conducted by Asmara et al, (2016)on management department students of a state university in East Java. This study aimed to determine the influence of need for achievement and risktaking propensity on entrepreneurial intentions with entrepreneurial attitudes as a mediating variable. The study concluded that the need for achievement and risk-taking propensity were proven to increase entrepreneurial intentions. In addition, entrepreneurial attitudes were shown to mediate the influence of need for achievement and risk-taking propensity on entrepreneurial intentions. Another research was conducted by Yohana \&Salsabila(2019) on students of the Faculty of Economics at a state university in DKI Jakarta. From both of these studies, object of research was students of the Faculty of Economics who are assumed to have obtained business knowledge basics from lectures. Meanwhile, this study was conducted on students across disciplines (both science and social humanities) whose basics of business science obtained from entrepreneurship courses in their course of study, but not strong enough as a basis for starting a business. Of course, these differences will be interesting to observe to see whether there are various results from the need for achievement, risk-taking propensity, entrepreneurial attitudes, and entrepreneurial intentions from previous research.

Individual who have a high level of need for achievement, are not easily satisfied with their performance and achievements and they keep trying to get more (Farrukh, 2018), they also tend to have the desire to be successful and consequently intend to become entrepreneurs(Chen et al., 2012). Referring to Purnomoet al.,(2019) almost $50 \%$ of Generation $Z$ will choose entrepreneurship as their career choice or do contract job. The desire to not be controlled by other people, high self-confidence that they are able to change the world, prioritizing social relations over work-life balance are their ways to achieve success in the future. The previous research recommendations underlie the first hypothesis:

$\mathrm{H}_{1}$ : Need for achievement has a positive influence on Generation Z entrepreneurial intentions

Risk taking propensity is "the willingness to be courageous and aggressive in pursuing opportunities and choosing high-risk projects with very high returns over low-risk projects with lower and more predictable returns" (Spicka, 2020). Starting a new business is always fraught with risks that affect the intention to become an entrepreneur. Uncertainty about business success becomes an obstacle that hinders an individual's intention to start a new business (Akhtar et al., 2020). Every action must be accompanied by precise calculations or measurements and decisions taken with care. In the findings of other researchers found that an entrepreneur tends to be innovative, creative, dynamic, flexible, risk-taking, and growth-oriented (Stevenson and Gumpert, 1985 in Antonic, 2018). By having risk-taking skills, entrepreneurs will be encouraged to continue to improve their business operations. So that entrepreneurial orientation tends to face more uncertainty, there are often a number of risks involved in the entrepreneurial process; Therefore, the higher the tendency to calculate risk, the higher the entrepreneurial intention (Yurtkoru, 2014). In other studies, it shows that individual who have a tendency to take high risks have a stronger incentive to engage in entrepreneurship (Farrukh, 2018). Based on these various opinions, a hypothesis was formulated:

$\mathrm{H}_{2}$ : Risk-taking propensity has a positive effect on Generation Z entrepreneurial intentions.

Through Planned Behavior Theory (PBT), it states that intentions are explained through behavioral attitudes, subjective norms, and perceived behavioral control (Kurjono, 2018). Based on this it can be concluded that one's intention to set up their own business may be a strong attitude towards entrepreneurial development (Gochhait, 2020). Being confident and optimistic, oriented to tasks and results, dare to take risks and like challenges, leadership, originality, future-oriented are the six characteristics of entrepreneurship that reflect the attitudes of 
an entrepreneur.

Several variations have been made by previous researchers to examine the indirect influence of need achievement and risk-taking propensity on entrepreneurial intention through entrepreneurial self-efficacy (Akhtar, et al.,(2020), Naushad \& Malik(2018). A research by Asmara et al.,(2016)on 540 management department students of a state university in Malang recommended that individuals who have high achievement motivation and risk-taking propensity skills will have positive entrepreneurial attitudes, and this will have an impact on increasing entrepreneurial intention.

$\mathrm{H}_{3}$ : Need for achievement has an influence on the entrepreneurial intention of Generation $\mathrm{Z}$ through entrepreneurial attitudes

$\mathrm{H}_{4}$ : Risk taking propensity has an indirect effect on the entrepreneurial intention of Generation $\mathrm{Z}$ through entrepreneurial attitudes.

\section{METHODS}

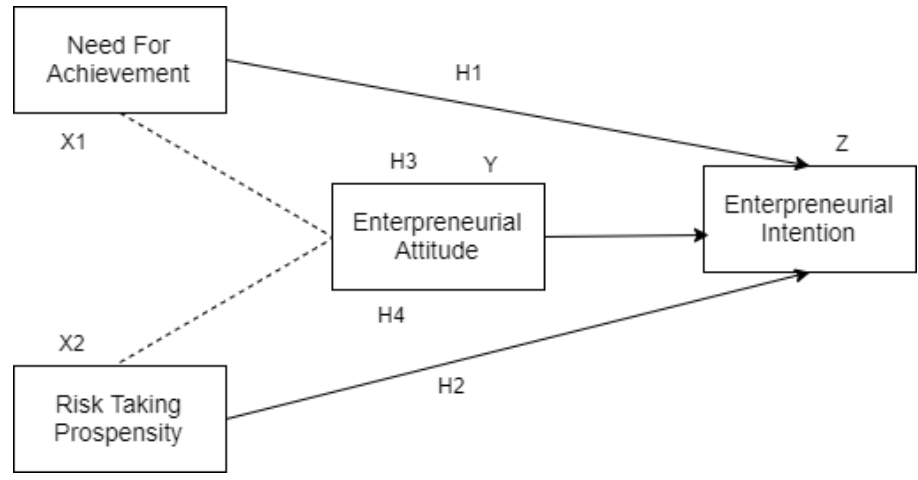

Figure 1. Research model

The research approach in this study was a quantitative research. A measurement of need for achievement using operationalization from Kristiansen (2004) and Fazlurrahman (2020). Risk-taking propensity measurement was based on a combination of General Risk Propensity (GRP) which has been validated by Spicka (2020) and Khodarahimi (2016) Entrepreneurial attitudes were measured based on a questionnaire from Ayalew(2018). Entrepreneurial intention was measured based on a questionnaire from Kristiansen (2004) and Fazlurrahman (2020).

The object used in this study was Airlangga University students who were assigned as participants of the Student Entrepreneurship Program (PMW) in 2020. The study population was 61 students who were members of the Student Entrepreneurship Program (PMW) Airlangga University Surabaya who had passed the selection of business assistance either in groups as well as individuals. Data dissemination was carried out through online questionnaires considering that August to September 2020 was still in the COVID19 pandemic situation which required the public to maintain distance to break the chain of the COVID19 transmission. Apart from questionnaires, online interviews were also conducted. The data resulted from distributing was ordinal scale questionnaires considering the questionnaires was distributed using a Likert scale, using a score of 1 (Strongly Disagree) to 5 (Strongly Agree).

The hypothesis testing technique used the path analysis because the Path Analysis is useful for estimating the causality relationship between variables (casual models) that have been previously determined.

\section{RESULTS AND DISCUSSIONS}

Based on the results of the questionnaire data processing, the respondents in this study can be described as follows:

Respondents who are older than 20-year age were 53 people or as much as $89.83 \%$, while respondents who are younger than 20-year age were 6 people or as much as 10.17\%. PMW 2020 participants consisted of 44 females (74.6\%), 15 males (74.6\%). Respondents who are older than 20-year age were 53 people or as much as $89.83 \%$. Respondents with the highest number were respondents with entrepreneurial experience of 52 people or as much as $88.13 \%$. Meanwhile, there were 7 respondents who did not have entrepreneurial experience or as much as $11.87 \%$.

To find out the mean value of respondents' answer to each questionnaire statement item and for each 
research variable, a questionnaire answer was recapitulated. In this case, the mean value of each questionnaire answer was calculated and analyzed for each variable, and then the mean value of the total questionnaire answers for each variable was analyzed. The interval used in categorization was obtained from the highest answer value (5) minus the lowest answer value (5) divided by the number of classes (5), so that the interval for categorization is 0.8 . After that, the variable categorization was carried out with the provision that the interval $1.00-1.80$ was classified as very low, the interval $1.81-2.60$ was classified as low, the interval $2.61-3.40$ was classified as sufficient, the interval $3.41-4.20$ was classified as high, and the interval $4.21-5.00$ was classified as very high.

The recapitulation results of the mean value of on the questionnaire item about the Need For Achievement variable can be seen in Table 2

Table 2 Recapitulation of The Mean Value of Questionnaire on the Variable of Need For Achievement

\begin{tabular}{lc}
\hline Questionnaire Items & Mean Value \\
\hline I have a strong need to be successful in starting business & 4.61 \\
I immediately evaluate mistakes of the tasks that have been given & 4.53 \\
I actively participate in the PMW mentoring program to hone my entrepreneurial skills & 4.24 \\
It is too bad to miss PMW activities & 4.15 \\
I can manage time for college time and learning to start business & 3.71 \\
I am willing to compete with other people & 3.90 \\
I am responsible for the decisions I make & 4.51 \\
\hline Total Mean Value of Need for Achievement Variable & 4.23 \\
\hline
\end{tabular}

Source: Data Processed by Researchers (2020)

Based on Table 2, the Need for Achievement has a mean value of 4.23, thus is categorized as very high. The results of the recapitulation of the mean value of questionnaire answers on the Risk-Taking Propensity variable can be seen as follows

Table 3. The recapitulation results of risk-taking propensity variables

\begin{tabular}{lc}
\hline Questionnaire Items & Mean Value \\
\hline I am open to new experiences & 4.54 \\
I am ready to accept entrepreneurial risks & 4.20 \\
I am ready to accept higher risks because I am aware of the consequences & 4.03 \\
I have the ability to calculate risks that will occur & 3.97 \\
I am on the lookout for every possible risk & 4.00 \\
I am willing to choose safer options & 4.19 \\
A high business risk does not make me hinder from business & 4.24 \\
A high number of competitors does not make me hinder from business & 4.25 \\
\hline Total Mean Value of Risk-Taking Propensity Variable & 4.18 \\
\hline Source: Data Processed by Researchers (2020) &
\end{tabular}

Based on Table 3, the mean value of answers for the risk-taking propensity variable is 4.18 , thus the abilities and desires of generation $\mathrm{Z}$ to take risks and calculate risks with entrepreneurial intentions is categorized as high. The recapitulation results of the mean value answers to the questionnaire on the entrepreneurial attitude variable can be seen in Table 4

Table 4 Recapitulation results of Entrepreneurial Attitude variable

\begin{tabular}{lc}
\hline Questionnaire Items & Mean Value \\
\hline I started out with a business that attracts the market & 4.31 \\
I have the provisions to run a business & 3.90 \\
I have a high opinion about business development & 4.32 \\
I have a positive view about business development & 4.56 \\
I can see business opportunity better than other people & 4.34 \\
I believe that all business opportunity will be profitable in the future & 4.39 \\
\hline Total Mean Value of Entrepreneurial Attitude & 4.30 \\
\hline
\end{tabular}

Table 4 shows that the mean value of answers for the entrepreneurial attitude variable is 4.30 . This shows that a positive attitude for generation $\mathrm{Z}$ towards business startup activities can be categorized as very good. The recapitulation results of the mean value of answers to the questionnaire on the entrepreneurial intention variable can be seen in Table 5 .

Table 5 The Recapitulation result of Entrepreneurial Intention variable 


\begin{tabular}{lc}
\hline Questionnaire Items & Mean Value \\
\hline I have a role model in entrepreneurship & 4.39 \\
I am determined to express my idea & 4.14 \\
I earnestly look for information about entrepreneurship & 4.41 \\
I will conduct preparations for entrepreneurship & 4.37 \\
I will realize what I gain from business development in the upcoming years & 4.17 \\
I will plan my business in an organized manner & 4.36 \\
I have solutions for the upcoming problems in entrepreneurship & 4.34 \\
\hline Total Mean Value & 4.31 \\
\hline Source: Data Processed by Researchers $(2020)$ &
\end{tabular}

Table 5 shows that the mean value of answers for the entrepreneurial intention variable is 4.31 . In addition, the desire of the $\mathrm{Z}$ generation to take entrepreneurial action by creating new products through business opportunities and taking risks is very high.

\section{Hypothesis Test Result}

Based on the validity test, the seven items in the Entrepreneurial Intention Variable have $\mathrm{R}$ count (Pearson correlation value) $>\mathrm{R}$ table $(0.2564)$ and a $\mathrm{P}$ value $<0.05$. Thus, the seven instrument items are declared valid. Based on the results of the reliability test, it can be seen that the variables need for achievement, risk-taking propensity, entrepreneurial attitudes and entrepreneurial intentions have a Cronbach's Alpha value of more than 0.6. This shows that all variables in this study are reliable and can be used in a research.

The Kolmogorov-Smirnov normality test results showed that the Asymp. Sig. (2-tailed) is 0.763 . This shows that the significance value is more than 0.05. Thus, the research data on all variables, namely need for achievement, risk-taking propensity, entrepreneurial attitudes and entrepreneurial intentions are distributed as normal.

The results of the heterokesdastic test showed that the variables need for achievement, risk-taking propensity, entrepreneurial attitudes and entrepreneurial intentions have a value of $\mathrm{Sig}>\alpha(0.05)$ so there is no heteroscedasticity. The three variables each have a value of $0.734 ; 0.653 ; 0.764$, which means that the three variables have a sig value $>0.05$. Thus, the three variables do not have heteroscedasticity.

The multicollinearity test results showed that the variables need for achievement, risk-taking propensity; entrepreneurial attitudes have tolerance values of $0.991 ; 0.993$; and 0.993 , and the VIF value respectively of $1.009 ; 1,008$; and 1,007. In accordance with the provisions that if the tolerance value is $>0.1$ and the VIF value is $<10$, then the model does not occur multicollinarsity. Thus, the three variables have a tolerance value $>0.1$ and a VIF value $<10$, then the models do not have multicollinarsity.

The Path Analysis is an extension of multiple linear regression analysis. The Path Analysis is useful for estimating the causality relationship between variables (casual models) that have been previously determined based on theory.

The first stage of Path Analysis was used to measure the power of the influence of Need for Achievement and Risk-Taking Propensity as independent variables on entrepreneurial attitudes as mediating variables. In the second stage, it was used to measure the influence strength of Need for Achievement, Risk-Taking Propensity, and Entrepreneurial Attitudes as independent variables on Entrepreneurial Intention as the dependent variable.

The Partial $\mathrm{T}$ test was conducted to determine how the influence of each variable, namely the Need for Achievement (X1) variable, the Risk Taking Propensity (X2) variable, and the Entrepreneurial Attitude (Y) variable as partially independent variables on the entrepreneurial intention $(Z)$ as a bound variable. The results of the partial T test are shown in Table 6 below:

Table 6. The Result of Partial T Test Coefficients $^{\Xi}$

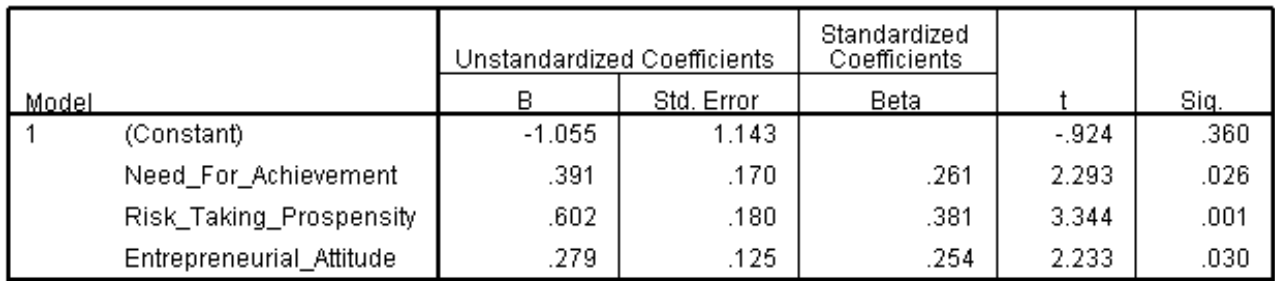

a. Dependent Variable: Entrepreneurial_Intention 
Based on the SPSS test on Table 6, the results showed that the Need for Achievement variable has a standardized coefficient beta value of 0.261 . The standardized coefficient beta value of 0.261 is the path value or path P3 (X1Z). The risk-taking propensity variable has a standardized coefficient beta value of 0.381 . The standardized coefficient beta value of 0.381 is the path value or path P4 (X2Z). The entrepreneurial attitude variable has a standardized coefficient beta value of 0.254 . The standardized coefficient beta value of 0.254 is the path value or path P5 (YZ). The $\mathrm{R}^{2}$ value shown is 0.293 , then as for the value of e2 with the formula $=$ $\sqrt{(1-0.293)}=0.841$. Hence, the model is described in accordance with the conceptual model analysis. The Path Analysis results are shown in Figure 2.

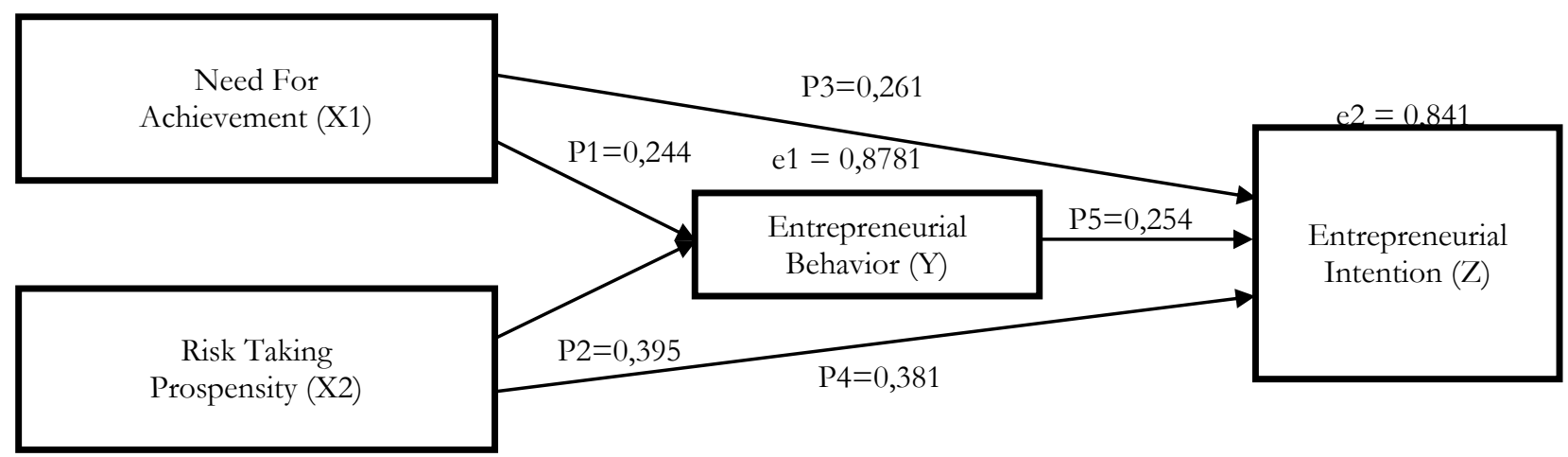

Figure 2ModelPath Analysis

In the path model, this study explained the direct and indirect influences of independent variable on the dependent variable which was mediated by the entrepreneurial attitude variable.

a. The influence of the need for achievement variable

- Direct Influence (Need For Achievement on Entrepreneurial Intention)

$=\mathrm{P} 3(\mathrm{X} 1 \mathrm{Z})=0.261$

- Indirect Influence (Need For Achievement on Entrepreneurial Intentions through Entrepreneurial Attitudes)

$=\mathrm{P} 1(\mathrm{X} 1 \mathrm{Y}) \times \mathrm{P} 5(\mathrm{YZ})=0.244 \times 0.254=0.0619$

Based on the results of the analysis of the direct and indirect influences of Need for Achievement on Entrepreneurial Intention, the direct effect value is 0.261 . While the indirect effect produces a value of 0.0619 . The total direct and indirect influence between Need for Achievement on Entrepreneurial Intention is 0.3229. It can be concluded that the total influence of Need for Achievement on Entrepreneurial Intention is 0.3229 and hence supports hypothesis 3 .

a. The influence of Risk-Taking Propensityvariable

- Direct Influence (Risk-Taking Propensity on Entrepreneurial Intention) $=\mathrm{P} 4(\mathrm{X} 2 \mathrm{Z})=0.381$

- Indirect Influence (Risk-Taking Propensity on Entrepreneurial Intention through Entrepreneurial Attitude)

$=\mathrm{P} 2(\mathrm{X} 2 \mathrm{Y}) \times \mathrm{P} 5(\mathrm{YZ})=0.395 \times 0.254=0.1003$

Based on the results of the analysis of the direct and indirect influences between risk-taking propensity on entrepreneurial intentions, the direct effect value is 0.381 . While the indirect effect produces a value of 0.1003 . The total direct and indirect influences between risk-taking propensity on entrepreneurial intentions are 0.4813 . It can be concluded that the total influence of risk-taking propensity on entrepreneurial intentions is 0.4813 and supports hypothesis 4 .

The following is an explanation of the significance value of each variable. The significance value as shown in Table 6 from the Need for achievement variable on the entrepreneurial intention variable is $0.026<\alpha=0.05$, hence the Need for achievement variable has a significant influence on the entrepreneurial intention variable, then hypothesis 1 is accepted. The significance value of the Risk-taking propensity variable on the entrepreneurial intention variable is $0.001<\alpha=0.05$, hence that the risk taking propensity variable has a significant effect on the entrepreneurial intention variable, then hypothesis 2 is accepted. The Need for 
Achievement has an indirect effect on entrepreneurial intention through entrepreneurial attitude as mediation. The total direct and indirect influence between need for achievement on entrepreneurial intention is $0.3229>\alpha=$ 0.05 and thus rejecting hypothesis 3. It can be concluded that entrepreneurial attitudes do not mediate the effect of risk-taking propensity on entrepreneurial intentions. The total direct and indirect influence between RiskTaking Propensity on Entrepreneurial Intention is $0.4813>\alpha=0.05$ thus rejecting hypothesis 4 . It can be concluded that entrepreneurial attitude does not mediate the influence of risk-taking propensity on entrepreneurial intention.

\section{The influence of need for achievement on the entrepreneurial intention of Generation $\mathrm{Z}$}

The intention of generation Z as a participants of PMW 2020 Airlangga University to take entrepreneurial actions by creating new products through business opportunities and taking risks has proven to be influenced by their desire to be successful through the business they are currently pioneering. The results of this study were in line with various previous studies by Akhtar, et al.,(2020), Yohana \&Salsabila(2019), Yumili\&Untu(2019). Asmara, et al.,(2016) that the increasing entrepreneurial intention among students is influenced by achievement motivation.

McClelland(2014) stated that the need for achievement in entrepreneurship cannot be separated from the desire to achieve (N-ach), being powerful (N-pow), the desire to affiliate (N-aff). Referring to the opinion of Purnomoet al.,(2019) Generation Z has a desire not to be ruled by others, has high self-confidence, prioritizing social relations over work-life balance so that they are able to change the world into their way of achieving success in the future.

Participating in PMW was one of the ways they prepared to become successful entrepreneurs in addition to other ways that are characteristic of Generation Z, namely through the support of technology and social media. The need for high achievement is also manifested by the presence of technology and social media which make it easier for Generation Z to get role models in entrepreneurship so that the desire to be entrepreneurial is getting higher.

There are things that need to be put in consideration, one of which is the difficulty in managing college life and starting a business. This reason always came up as an obstacle conveyed by students when starting a business. PMW 2020 was implemented during the COVID-19 pandemic, where implementation was carried out online. Online implementation both in lecture activities and student activities faced challenges in delivering material and providing feedback.

The implementation of PMW also encountered obstacles. Previously, projects and project evaluations could easily be conducted directly, whilst currently they had to move online. The consequence of being online is the mixed-up implementation of projects. For example, market validation on prospective consumers must be done through the media WhatsApp, Google Meet, Zoom or Google Form. This required time adjustments with consumers, as well as it took time to compile project reports. Nevertheless, this did not dampen their desire to become entrepreneurs. In response to this, time management training and effective group work could be provided.

The results of this study were in line with the results of research by Hartono(2018) who conducted a research on 100 participants of entrepreneurial student programs from public and private universities in Indonesia. The results of this study concluded that students' concerns over the ability to manage time between college and entrepreneurship were relatively reasonable, because the responsibility for completing their studies made it impossible to fully concentrate on business or entrepreneurship.

\section{The influence of risk-taking propensity on the entrepreneurial intention of Generation $\mathrm{Z}$}

The intention of generation Z as a participants of PMW 2020 Airlangga University to take entrepreneurial actions by creating new products through business opportunities has been proven to be influenced by their attitude in taking risks and calculating risks. The results of this study supported a previous research from Scafarto, et al., (2019) and Guet al.,(2018) which stated that entrepreneurial intentions are influenced by courage in taking risks.

There were interesting findings from the responses of respondents about risk for propensity to the statement "I am open to new experiences" that got the highest average and conversely the responses to the questions "I am open to new experiences" and "I have the ability to calculate the risks that will occur". Even though it is still considered as high, it is classified as the lowest in average among the other questions, thus it is interesting to discuss further.

Participants in PMW 2020 Airlangga University did not only come from students of the faculty of economics. There were also students from various disciplines, where they get entrepreneurial insights from entrepreneurship courses alone. Of course this does not guarantee them to get detailed information about business risks as well as 
students who come from faculty of Economics. This had an impact on their prudence in making business decisions. Therefore, they really hoped for the details of risk in business. Especially during the COVID-19 pandemic, participants needed information on how to make adjustments to the business they had started so that they could survive and would not face the risk of business failure.

In addition, the motivation to participate in PMW was to expect assistance from mentors who are members of PMW mentors of Airlangga University. The opportunity to consult with mentors is a way to increase their confidence in facing risks in addition to other ways that are typical for Generation Z who rely on information technology and social media, where all the information needed can be easily and quickly accessed for the benefit of daily life, as well as their business interests.

The explanation from Generation Z of PMW 2020 participants at Airlangga University indicated that risktaking skills are considered important, because entrepreneurship is not enough to rely on intuition, and every action must be accompanied by precise calculations or measurements, as stated by Gürol\&Atsan(2006).

\section{The influence of need for achievement on the entrepreneurial attitude of Generation $\mathrm{Z}$}

The entrepreneurial attitude was proved to be unable to mediate the need for achievement towards the entrepreneurial intention of generation Z who participated in PMW 2020 at Airlangga University. This result was certainly very interesting for further review because the high entrepreneurial attitude mean value, in fact, could not mediate a high ambition for success and a strong intention to become entrepreneurs. The result of this study did not support the results of a study by Asmara et al,. (2016)which stated that attitudes are proven to be able to mediate the effect of the need for achievement on the entrepreneurial intention of management department students at the Universitas Negeri Malang. The majority of respondents in the study were 20 years old (born around 1996), so it can be concluded that in that study, they were classified as the millennial generation (Iswahyudi \& Iqbal, 2018).

Generation Z was born from a combination of the previous two generations namely Generation $\mathrm{X}$ and Generation Y. People in this generation are those who were born and raised in the digital era, where various kinds of technology have developed more and more and are sophisticated(Pratama \& Yanuar, 2012). This directly or indirectly affects the development of behavior, personality, even education and learning outcomes.

Santosa(2015) stated that Generation Z is also known to have high ambitions to succeed, eager to gain recognition, and being meticulous (because they can easily get various information in cyberspace). On the downside, generation $Z$ is less skilled in verbal communication because this generation $Z$ tends to spend time through cyberspace and social media rather than spending time face to face with other people, so they are known as the anti-social generation. Secondly, according to Iswahyudi\& Iqbal, (2018)millenial generation is less like process, they are generally impatient and like instant thing. It seems that this also happened in generation $\mathrm{Z}$ inthis research.

The presence of information technology in the form of Youtube, Facebook, Instagram, Twitter and LinkedIn shows the success of an entrepreneur along with practical tips in managing a business has amazed Generation $\mathrm{Z}$ to start owning their own business (Purnomo et al., 2019). The high need for achievement and high entrepreneurial intention from generation Z participants of PMW Airlangga University illustrated a high ambition to succeed, but it was not accompanied by an entrepreneurial attitudes. In fact, attitude is an important character that influences the mindset and behavior of an individual to be able to show their entrepreneurial intentions (Meredith, 2000)

In response to this, it is necessary to conduct certain approach Generation $Z$ so that entrepreneurial attitudes can support their desire for achievement and their intention to become entrepreneurial. According to Tridhonanto\&Beranda Agency(2014), approaches that can be done for generation Z include role modeling, accustoming discipline, encouragement, and giving rewards. PMW implementers can bring business practitioners to share their experiences of upholding an attitude, especially when interacting with stakeholders (namely potential investors, customers, suppliers and employees) so that this supports the success of their business. Increasing their awareness of the process is also equally important. This can be done by providing trainings that emphasize the importance of processes in various ways (for example: production, service, marketing, and financial reporting). The results will be more optimal if accompanied by sharing experiences from business practitioners about the importance of processing in order to maintain the quality of their business.

\section{The influence of risk-taking propensity on the entrepreneurial intention of Generation $\mathrm{Z}$ through entrepreneurial attitude}

The entrepreneurial attitude also proved unable to mediate the risk-taking propensity against the entrepreneurial intentions of generation Z who participated in PMW 2020 at Airlangga University. This result 
was certainly very interesting to discuss in more depth considering that the mean value of entrepreneurial attitudes is classified as high but in fact it cannot mediate the effect of courage to take risks on the intention of generation $Z$ in entrepreneurship. Thus, the results of this study did not support the results of Asmara et al.,(2016)which stated that attitudes are proven to be able to mediate the influence of the courage to take risks on the entrepreneurial intention of the management department students at the Universitas Negeri Malang.

From these results, it seems that the compatibility between the abilities and desires of generation $\mathrm{Z}$ participants of PMW Airlangga University in 2020 in taking risks and calculating risks with entrepreneurial intentions without being accompanied by entrepreneurial attitudes. The confidence to be able to take risks cannot be separated from the information technology environment that accompanies Generation Z, where they could easily get all kinds of information related to the business they have started. They could easily get tips from successful entrepreneurs in cyberspace. However, if they did not practice the tips by themselves, accompanied by patience and diligence in undergoing a process, of course they would not hone their abilities to become capable entrepreneurs. It seems that what happened in this $Z$ generation was not much different from the previous generation namely the millennial generation, where entrepreneurship must be followed by the ability to carry out entrepreneurial analysis(Arrighetti et al., 2014).

In addition, it was suspected that the PMW 2020 implementation factor which took place in the midst of the COVID-19 pandemic which requires people to carry out social distancing has affected the entrepreneurial attitude of Generation Z as participants both individually and in groups. Risk-taking propensity was manifested by running product sales projects meanwhile the targets were not matched by a decrease in consumer purchasing ability. The intended consumers prioritized their spending on health and survival matters in the midst of the COVID-19 pandemic.

Another thing about the implementation of PMW is that it coincided with the holy month of Ramadan and continued during the Final Semester Examination period, so that a number of virtual meetings in the form of routine training and mentoring were canceled. This created an impact on not delivering training materials, and discussions with mentors about business progress were not carried out properly, whereas these activities were designed to equip participants to be more skilled in developing their business. The basis for the preparation of these activities was the diverse scientific backgrounds of PMW participants so that intensive training and business mentoring is required.

\section{CONCLUSIONS}

Based on the hypothesis test results in this study and the analysis that has been conducted by the authors, what can be implied from the study is as follows: Need for achievement and risk-taking propensity was proven to have an influence on the intention to entrepreneurship in Generation Z. Entrepreneurial attitudes are proven unable to mediate the influence of Need for achievement and risk for propensity on the intention to become a generation $Z$ entrepreneur.

For PMW implementers, it is encouraged to redesign entrepreneurship coaching programs in accordance with Generation Z characteristics, especially in terms of entrepreneurial attitudes. Various approaches can be developed to create positive attitudes for Generation Z towards their business activities so that a high desire to succeed in realizing entrepreneurial intentions is achieved.

\section{REFERENCES}

Akhtar, S., Hongyuan, T., Iqbal, S., \& Ankomah, F. Y. N. (2020). Impact of Need for Achievement on Entrepreneurial Intentions; Mediating Role of Self-Efficacy. Journal of Asian Business Strategy, 10(1). https://doi.org/10.18488/journal.1006.2020.101.114.121

Antonic, Jasna Auer., Antoncic, B., Gantar, Matjaz., Hisrich, Robert D., Marks, Lawrence J., Bachkirov, Alexandre A., Li, Zhaoyang., Pierre Polzin, Borges, Jose L., Coelho, Antonio., Kakkonen, Marja-Liisa. (2018). Risk-Taking Propensity and Entrepreneurship:The Role of Power Distance. Journal of Enterprising Culture, 26 (1).https://doi.org/10.1142/S0218495818500012

Arrighetti, A., Landini, F., \& Lasagni, A. (2014). Intangible assets and firm heterogeneity: Evidence from Italy. Research Policy, 43(1). https://doi.org/10.1016/j.respol.2013.07.015

Asmara, H. W., Tri Djatmika, E., \& Indrawati, A. (2016). The Effect of Need for Achievement and Risk Taking Propensity on Entepreunerial Intention through Entepreunerial Attitude. IOSR Journal of Business and Management, 18(6). 
Ayelaw, Mesfin Mulu andZeleke, Shumet Amare. (2018). Modeling the impact of entrepreneurial attitude on selfemployment intention among engineering students in Ethiopia.Journal of Innovation and Entrepreneurship7(8).

Chen, S., Su, X., \& Wu, S. (2012). Need for achievement, education, and entrepreneurial risk-taking behavior. Social Behavior and Personality, 40(8). https://doi.org/10.2224/sbp.2012.40.8.1311

Farrukh,Muhammad., Alzubi, Yazan., Shahzad, Imran Ahmad., Waheed, Abdul., Kanwal, Nagina. (2018). Entrepreneurial intentions The role of personality traits in perspective of theory of planned behaviour. Asia Pacific Journal of Innovation and Entrepreneurship, 2398-7812. https:// doi.org/10.1108/APJIE-01-2018-0004.

Fazlurrahman, Hujjatullah. (2020). Measuring Entrepreneurship Intention With Need For Achievement, Locus Of Control, Self-Efficacy, And Readiness Instrument: Business And Engineering Student In Indonesia. International Journal of Management, Innovation \& Entrepreneurial Research, 6(1).

Fitzsimmons, J. R., \& Douglas, E. (2005). Entrepreneurial Attitudes and Entrepreneurial Intentions: A CrossCultural Study of Potential Entrepreneurs in India, China, Thailand and Australia. Babson-Kauffman Entrepreneurial Research Conference, 1-19.

Gochhait, Saikat. (2020). Entrepreneurial (Attitude, Orientation and Intention) Among Various Categories of Students. European Journal of Molecular \& Clinical Medicine, 7(1).

Gonzales, R. G. (2011). Learning to be illegal: Undocumented youth and shifting legal contexts in the transition to adulthood. American Sociological Review, 76(4). https://doi.org/10.1177/0003122411411901

Gu, J., Hu, L., Wu, J., \& Lado, A. A. (2018). Risk Propensity, Self-Regulation, and Entrepreneurial Intention: Empirical Evidence from China. Current Psychology, 37(3). https://doi.org/10.1007/s12144-016-9547-7

Hartono, H. (2018). Kajian Capaian Program Mahasiswa Wirausaha. Jurnal Aktual Akuntansi Kenangan Bisnis Terapan (AKUNBISNIS), 1(2). https://doi.org/10.32497/akunbisnis.v1i2.1230

Henley, W. (2017, May 15). Generasi Millenial, UMKM, dan Media Pemasaran Digital. Republika. https://www.republika.co.id/berita/jurnalisme-warga/wacana/17/05/15/opziw5396-generasi-millenialumkm-dan-media-pemasaran-digital

Hisrich, R., Langan-Fox, J., \& Grant, S. (2007). Entrepreneurship Research and Practice: A Call to Action for Psychology. American Psychologist, 62(6). https://doi.org/10.1037/0003-066X.62.6.575

Iswahyudi, M., \& Iqbal, A. (2018). Minat Generasi Milenial untuk Berwirausaha. Jurnal Akuntasi Dan Pendidikan, $7(2), 95$.

Khodarahimi, Siamak., and Fathi, Rayhan. (2016). Mental Health, Coping Styles, and Risk-Taking Behaviors in Young Adults. Journal Of Forensic Psychology Practice, 16 (4), 287-303.

Koe, W.-L., Sa'ari, J. R., Majid, I. A., \& Ismail, K. (2012). Determinants of Entrepreneurial Intention Among Millennial Generation. Procedia - Social and Behavioral Sciences, 40, 197-208. https://doi.org/10.1016/j.sbspro.2012.03.181

Kolvereid, L. (1996). Organizational Employment versus Self-Employment: Reasons for Career Choice Intentions. Entrepreneurship Theory and Practice, 20(3). https://doi.org/10.1177/104225879602000302

Kristiansen, Stein., and Indarti, Nurul. (2016). Entrepreneurial Intention Among Indonesian And Norwegian Students. Journal of Enterprising Culture, 12(1).

Kurjono, Mulyani,Heni., Murtadlo, Yusuf. (2018). A Model of Entrepreneurial Intention Through Behavioral Approaches. Dinamika Pendidikan, 13(2), 185-197.
McClleland,
D.
(2014).
Human
Motivation.
Cambridge
University

Press.https://doi.org/10.1017/CB09781139878289 
Meredith, G. (2000). Kewirausahaan: Teori Dan Praktek (2000th ed.). Pustaka Binaman Pressindo.

Naushad, M., \& Malik, S. A. (2018). The mediating effect of entrepreneurial self-efficacy in entrepreneurial intention - A study in Saudi Arabian context. Problems and Perspectives in Management, 16(1). https://doi.org/10.21511/ppm.16(1).2018.26

Pratama, H., \& Yanuar, J. (2012). Cyber Smart Parenting, Kiat Menghadapi dan Mengasub Generasi Digital. Pt.Visi anugerah Indonesia.

Purnomo, A., Asitah, N., Rosyidah, E., Septianto, A., Daryanti, M. D., \& Firdaus, M. (2019). Generasi Z Sebagai Wirausaha. Osf, 4. https://doi.org/10.31227/osf.io/4m7kz

Rohrmann, B. (2005). Risk Attitude Scales: Concepts, Questionnaires, Utilizations. University of Melbourne, January.

Santosa, E. T. (2015). Raising Children in Digital Era. PT Elex Media Komputindo.

Scafarto, F., Poggesi, S., \& Mari, M. (2019). Entrepreneurial Intentions, Risk-Taking Propensity and Environmental Support: The Italian Experience. In Contributions to Management Science. https://doi.org/10.1007/978-3-030-19685-1_10

Spicka, Jindrich (2020). Socio-demographic drivers of therisk-taking propensity ofmicro farmersEvidence from the Czech Republic. Journal of Entrepreneurship in Emerging Economies.2053-4604. https://doi.org/10.1108/JEEE-09-2019-0143

Sumadi, A., \& Sulistyawati, E. (2017). Pengaruh Sikap, Motivasi, Dan LingkunganTerhadap NIAT Berwirausaha. None, 6(2).

Tridhonanto, \& Agency, B. (2014). Pengembangan Pola Asub Demokratis. PT. Gramedia.

Unair News. (2018, February 25). Selain Sarjana, UNAIR Siapkan Mahasiswa Jadi Wirausaha. University of Airlangga. http://news.unair.ac.id/2018/02/25/selain-sarjana-unair-siapkan-mahasiswa-jadi-wirausaha/

Untu, Y. I., \& Widjaja, O. H. (2019). Pengaruh Need For Achievement Dan Self-Efficacy Terhadap Entrepreneurial Intention Pada Mahasiswa Fakultas Ekonomi Universitas Tarumanagara. Jurnal Manajerial Dan Kewirausahaan, I(Volume I, No. 2, (2019), Jurnal Manajerial dan Kewirausahaan).

Verheul, I. (2003). Early Development of Entrepreneurial Qualities: The Role of Initial Education. Journal of Entrepreneurship Education, 2(2).

Yohana, C., \& Fatun Salsabila, A. (2019). Relationship Between Self-Efficacy and the Need for Achievement With Entrepreneurship Among Students of Jakarta State University, Faculty of Economics. KnE Social Sciences, 3(11). https://doi.org/10.18502/kss.v3i11.4032

Yurtkoru,E. Serra., Acar, Pınar., Teraman, Begüm Seray. (2014). Willingness to take risk and entrepreneurial intention of university students: An empirical study comparing private and state universities. Procedia - Social and Behavioral Sciences. https://doi.org/10.1016/j.sbspro.2014.09.092

Zamzami, Z. (2016). Analisis Faktor - Faktor Yang Memengaruhi Intensi Berwirausaha Pada Mahasiswa Universitas Brawijaya. Jurnal Ilmiah Mahasiswa FEB Universitas Brawijaya, 3(2), 1-25.

Zhao, H., Hills, G. E., \& Seibert, S. E. (2005). The mediating role of self-efficacy in the development of entrepreneurial intentions. Journal of Applied Psychology, 90(6). https://doi.org/10.1037/0021-9010.90.6.1265 